\title{
Kompetensi guru dalam meningkatkan mutu pembelajaran di sekolah dasar
}

\author{
Rosni Rosni*) \\ Sekolah Dasar Negeri 19 Mandau, Duri, Kabupaten Bengkalis, Indonesia
}

\begin{tabular}{l} 
Article Info \\
\hline Article history: \\
Received Sep $14^{\text {th }}, 2021$ \\
Revised Oct $23^{\text {rd }}, 2021$ \\
Accepted Nov $24^{\text {th }}, 2021$ \\
\hline
\end{tabular}

\section{Keyword:}

Teacher competencies

Student learning

Bengkalis

\begin{abstract}
ABSTRAK
Kompentensi guru dalam mengajar merupakan suatu hal yang sangat penting untuk disupervisi. Kemampuan ini berkaitan erat dengan kemampuan guru mengajar dikelas. Hal itu meliputi kemmapuan mengelola kelas dan kemampuan guru dalam melakukan interaksi dengan peserta didik Tujuan penelitian ini untuk menganalisis beberapa kompetensi guru meliputi kompetensi guru dalam kompetensi pedagogik, kompetensi kepribadian, kompetensi sosial, kompetensi profesional guru. Metode penelitian menggunakan pendekatan analisis deskriptif kualitatif. Hasil penelitian menunjukkan bahwa guru telah menerapkan kompetensi pedagogik, kompetensi kepribadian, kompetensi sosial, dan kompetensi professional dalam pembelajaran di kelas namun masih perlu ditingkatkan. Ini ditunjukkan oleh data kompetensi penyusunan silabus dan RPS dalam kategori baik, tetapi kompetensi penerapannya dalam pembelajaran masih dalam kategori kurang baik. Disarankan agar guru dapat meningkatkan kompetensinya dalam pembelajaran di kelas dengan mengikuti berbagai pelatihan pengembangan kompetensi.
\end{abstract}

(C) 2021 The Authors. Published by IICET.

This is an open access article under the CC BY-NC-SA license (https://creativecommons.org/licenses/by-nc-sa/4.0

\section{Corresponding Author:}

\section{Rosni Rosni}

Sekolah Dasar Negeri 19 Mandau

Email: rosniismail21@gmail.com

\section{Pendahuluan}

Kompetensi guru sangat diperlukan terutama menghadapi perkembangan pesat era digital saat ini. Guru memegang peran kunci dalam mencapai tujuan Pendidikan. Berbagai upaya telah dilakukan pemerintah untuk meningkatkan kompetensi guru di Indonesia. UNESCO juga telah memberikan kerangka kompetensi guru (Unesco, 2011), demikian pula kemendikbud telah membuat panduan penilaian kompetensi guru (Permendikbud No 16 Tahun 2007 Tentang Kompetensi Guru, 2007).

Saat menilai kompetensi pedagogik, kualitas pengajaran harus menjadi pertimbangan utama. Cakupan, keluasan, dan kedalaman juga penting, seperti halnya kemampuan untuk merencanakan, memulai, memimpin, danmengembangkan pendidikan dan pengajaran, serta kemampuan menyelenggarakan pengajaran berbasis penelitiandasar penelitian dalam mata pelajaran yang relevan, didaktik mata pelajaran dan belajar mengajar dipendidikan yang lebih tinggi. Kemampuan untuk berinteraksi pada isu-isu yang berkaitan dengan belajar mengajar di tingkat yang lebih tinggi pendidikan dengan individu yang aktif baik di dalam maupun di luar universitas juga termasuk dalam konsep kompetensi pedagogic (gambar 1). Kompetensi pedagogis didasarkan pada pengetahuan yang baik, luas dan terkini dalam subjekdaerah, serta pengetahuan belajar siswa dan belajar mengajar berbasis mata pelajaranmasalah. Ini juga mengandaikan pendekatan 
reflektif dan kritis untuk mengajar, belajar dan pengembangan pedagogis dari waktu ke waktu, karena terkait dengan peran profesionalnya sendiri. Pengajaran berbasis riset dan penelitian individu itu sendiri merupakan komponen penting dalam hal memenuhi dasar ilmiah tersebut. Kompetensi pedagogik ditunjukkan oleh pengajaran yang berhasil dan pengembangan pengajaran serta oleh evaluasi dan siswa sedang belajar. Area penilaian untuk menilai kompetensi pedagogis antar lain: 1) keterampilan mengajar, 2) Pengetahuan teoretis dan 3) Pendekatan yang bercirikan kemauan dan kemampuan untuk berkembang (Olsson \& Apelgren, 2010); Pada tingkat kognitif dan komponen prilaku, kompetensi pedagogic terpenting menurut persepsi siswa adalah metode dan teknik belajar mengajar, karena itu perlu mengidentifikasi dan mengukur kompetensi pedagogis guru dan kedepan ini merupakan tantangan dalam jalur pengembangan professional individu guru yang berkualifikasi tinggi (Mâță et al., 2013). Terdapat empat kompetensi guru yang harus dimiliki antara lain kompetensi pedagogik, kompetensi kepribadian, kompetensi sosial, dan kompetensi professional (Permendikbud No 16 Tahun 2007 Tentang Kompetensi Guru, 2007). Sejumlah studi telah banyak dilakukan untuk menilai kompetensi guru.

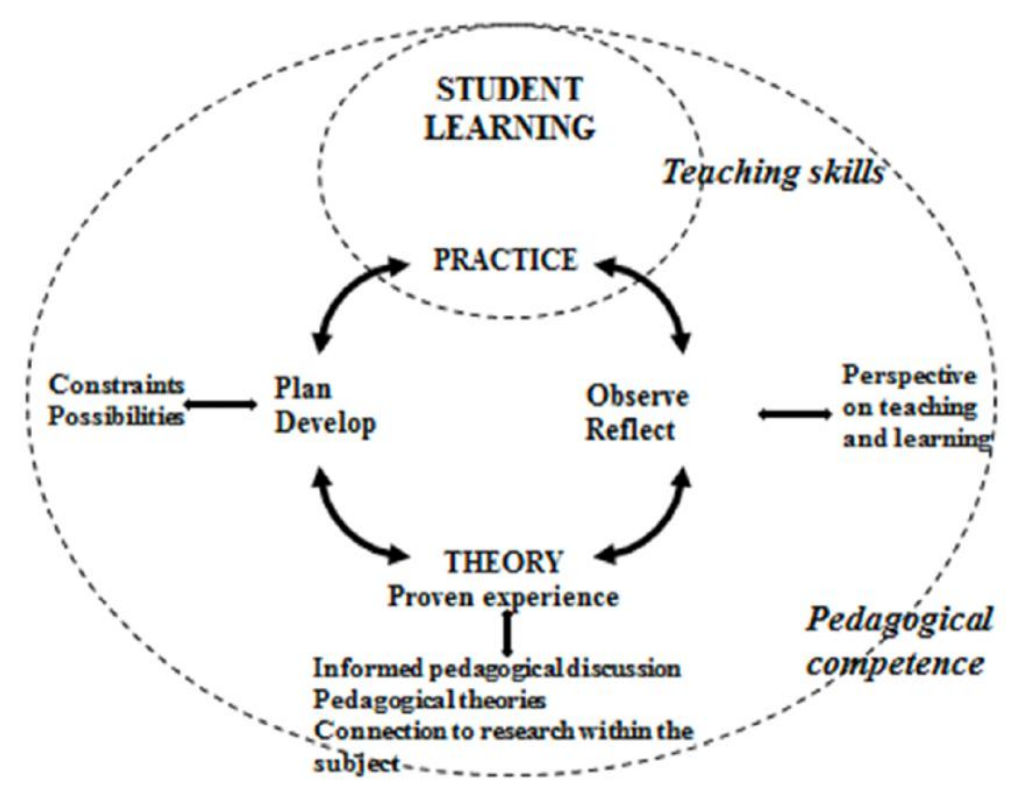

Gambar 1. Konsep Kompetensi Pedagogik

Terdapat pengaruh yang signifikan dari masing-masing kompetensi profesional (pedagogik, personal, profesional, dan sosial) terhadap kinerja guru. Kompetensi pedagogic merupakan bagian dari upaya mendukung terwujudnya pendidikan yang berkelanjutan. Tiga dimensi penting yang harus saling terintegrasi untuk mewujudkan sekolah yang berkelanjutan adalah dimesi social, ekonomi dan lingkungan. Namun dalam penelitian (Gunansyah et al., 2021) konsep yang diterapkan dalam pendidikan di sekolah masih terpisah antara aspek lingkungan, social dan ekonomi. Faktor dominan yang mempengaruhi kinerja guru adalah kompetensi social (Taniredja \& Abduh, 2016). Dalam temuan lain dikatakan bahwa kompetensi kepribadian sangat berpengaruh terhadap kinerja guru (Wardoyo, 2015). Dalam hal kompetensi professional ditemukan permasalahan kompetensi komunikatif dianggap sebagai tema masalah kompetensi professional. Sehingga penggunaan informasi dan komunikasi sangat penting dalam komunikasi yang efektif (Syamsinar \& Jabu, 2016). guru diharapkan mampu menciptakan komunikasi yang efektif kepada siswanya selama atau di luar kegiatan pengelolaan kelas. Selain itu, karena komunikasi yang efektif antara guru dan siswa adalah kunci guru untuk menjadi guru yang ideal, guru tidak boleh mengabaikan semua hambatan yang ditemukan selama interaksinya dengan siswa. Kompetensi sosial guru sangat berperan penting dalam meningkatkan kualitas pengajaran dan pembelajaran siswa (Ferdiaz Saudagar, 2014).

Dari beberapa penelitian diketahui bahwa berbagai cara dapat dilakukan untuk meningkatkan kompetensi guru antara lain; guru dan manajemen sekolah perlu mendorong agar siswa dapat terbuka menyampaikan permasalahan yang dihadapinya kepa da guru BK baik masalah pribadi, belajar dan social lainnya. Sehingga kerjasama yang baik dapat terbangun dan penyelesaian masalah segera teratasi (Khofifah et al., 2017). Salah satu keterampilan yang perlu dimiliki untuk itu adalah keterampilan mendengarkan (Aminah, 2018). Guru harus memiliki Teknik mengajar yang dapat meningkatkan motivasi belajar siswa dan ini dapat dilakukan dengan meningkatkan keterampilan social siswa (Muslim et al., 2021). 
Oleh karena itu sebagai langkah awal dalam upaya mendukung terciptanya sekolah dan Pendidikan yang berkelanjutan pada SDN 019 Mandau Kecamatan Duri Kabupaten Bengkalis perlu diketahui bagaimana kompetensi guru dari dimensi kompetensi pedagogic, kepribadian, social dan professional. Tujuan dari penelitian ini adalah untuk mengetahui bagaimana kompetensi pedagogik, kompetensi kepribadian, kompetensi sosial, kompetensi profesional guru SDN 019 di Mandau Kabupaten Bengkalis ini.

\section{Metode}

Berdasarkan variable yang perlu diukur dalam menilai kompetensi guru maka secara konseptual kerangka penelitian dapat dilihat pada gambar 2 berikut.

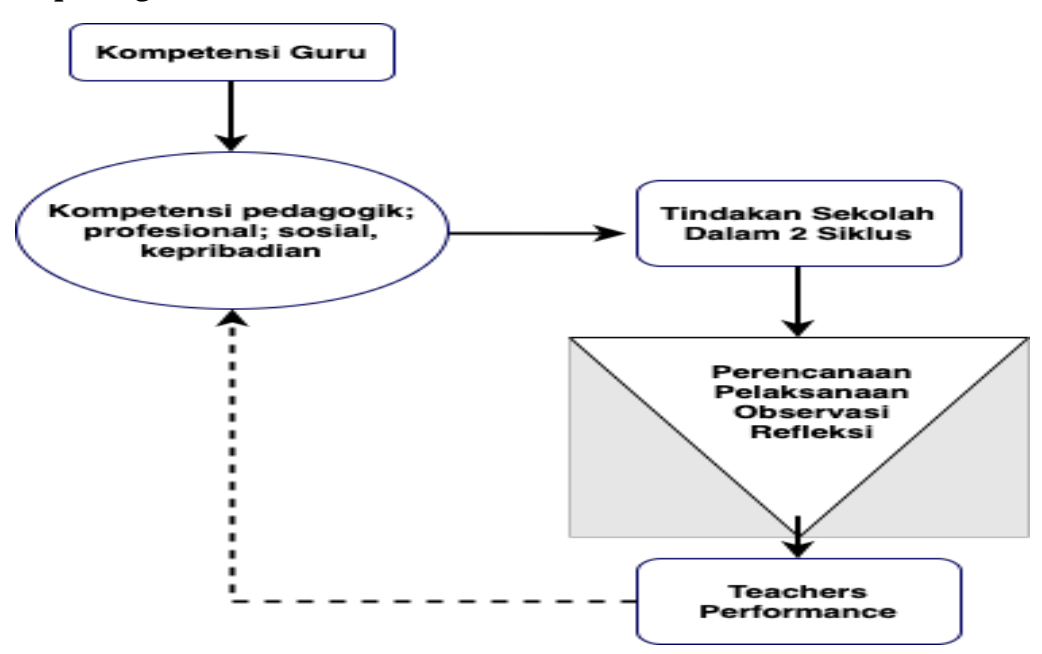

Gambar 2. Kerangka Penelitian

Pendekatan penelitian ini menggunakan data kualitatif yang merupakan suatu pendekatan dalam melakukan penelitian yang berorientasi pada penomena atau gejala yang bersifat alami yang biasa disebut dengan Field study atau naturalistic inquiry,"Pendekatan naturalistik digunakan untuk mencari dan menemukan pengertian atau pemahaman tentang fenomena apa yang dialami oleh subjek penelitian misalnya perilaku, persepsi, motivasi, tindakan. Secara holistik, dan dengan cara deskripsi dalam bentuk kata-kata dan bahasa, pada suatu konteks khusus yang alamiah dan dengan memanfaatkan berbagai metode alamiah.

Penelitian ini dilakukan dengan metode penelitian tindakan sekolah yang berlangsung selama 2 siklus. Masing-masing siklus terdiri dari tahapan perencanaan, pelaksanaan, observasi dan refleksi. Metode penelitian yang dilakukan peneliti adalah dengan melaksanakan supervise akademik yang meliputi supervise tradisional dan supervise klinis. Pada perencanaan siklus pertama terdapat beberapa kegiatan yaitu : (1) identifikasi masalah; (2) pengajuan proposal; (3) mempersiapkan instrumen. Tahap perencanaan pada siklus kedua dilakukan pertemuan dengan kolaborator untuk menyusun penjadwalan kemampuan meningkatkan mutu sekolah dan menyiapkan instrument pembelajaran untuk siklus kedua.

Jenis penelitian ini adalah penelitian deskriptif analitik yakni suatu penelitian yang bertujuan untuk memberikan gambaran tentang realitas pada obyek yang diteliti secara obyektif, oleh karena itu bentuk datanya adalah kualitatif. Penilaian menggunakan kriteria sebagai berikut; $1=$ sangat tidak baik; $2=$ tidak baik; 3 = kurang baik ; 4 = baik dan $5=$ sangat baik. Dengan pedoman penafsiran skor sebagai berikut: 1) Jumlah skor 0-10 sangat tidak baik ; 2) Jumlah skor 11-20 tidak baik; 3) Jumlah skor 20-30 kurang baik; 4) Jumlah skor 30-40 baik; 5)Jumlah skor 40-50 sangat baik.

\section{Hasil dan Pembahasan}

Hasil penelitian terhadap variabel kompetensi guru dalam menyiapkan perangkat pembelajaran seperti Silabus dan RPP menunjukkan kualitas guru dalam penyiapan Silabus dan RPP tergolong sudah baik. Ini ditunjukkan pada data jumlah nilai skor penilaian yang berada pada kisaran 24 - 31 yang menunjukkan kategori baik. Hal ini secara rinci dapat dilihat pada tabel 1. 
Tabel 1. Hasil Penilaian terhadap Kualitas Guru dalam Membuat Silabus dan RPP

\begin{tabular}{lccc}
\hline \multicolumn{1}{c}{ Indikator Yang Diamati } & \multicolumn{2}{c}{ Nilai Skor } \\
& $\begin{array}{c}\text { Kelas } \\
\text { Kelas } \\
\text { IV }\end{array}$ & $\begin{array}{c}\text { Kelas } \\
\text { VI }\end{array}$ \\
\hline $\begin{array}{l}\text { RPP yang ditulis guru ternyata sesuai dengan silabus - Silabus yang disusun } \\
\text { guru sesuai dengan standar isi/kurikulum }\end{array}$ & 3 & 4 & 4 \\
$\begin{array}{l}\text { Pembelajaran yang dilakukan sesuai dengan RPP } \\
\text { Dokumen dan bahan lain yang diperiksa RPP dan silabus Kegiatan/aktivitas } \\
\text { guru dan peserta didik selama pengamatan }\end{array}$ & 3 & 4 & 4 \\
$\begin{array}{l}\text { Guru mengaitkan materi pembelajaran tentang percobaan dalam kehidupan } \\
\text { sehari-hari }\end{array}$ & 3 & 3 & 4 \\
$\begin{array}{l}\text { Guru menjelaskan materi dengan lancar } \\
\text { Guru melaksanakan langkah-langkah kegiatan pembelajaran sesuai dengan }\end{array}$ & 3 & 4 & 3 \\
$\begin{array}{l}\text { RPP } \\
\text { Guru memberikan pertanyaan kepada siswa baik pertanyaan terbuka maupun } \\
\text { pertanyaan untuk dijawab secara individu }\end{array}$ & 4 & 4 & 4 \\
Guru memberikan pujian kepada siswa yang berani bertanya & 4 & 4 & 4 \\
\multicolumn{1}{c}{ Skor } & 4 & 4 & 4 \\
\hline
\end{tabular}

Sumber : Olahan Data Primer

Kemudian hasil penelitian terhadap variabel kompetensi guru dalam pengelolaan pembelajaran menunjukkan hasil analisis kualitas guru dalam pengelolaan pembelajaran di kelas masih kurang baik. Ini ditunjukkan pada jumlah skor penilaian yang berada pada kisaran angka $16-23$ yang berarti kurang baik. Hal ini ditunjukkan secara rinci pada tabel 2.

Tabe1 2. Hasil Penilaian terhadap Kualitas Guru dalam Pengelolaan Pembelajaran di Kelas

\begin{tabular}{|c|c|c|c|}
\hline \multirow[t]{2}{*}{ Indikator Yang Diamati } & \multicolumn{3}{|c|}{ Nilai Skor } \\
\hline & Kelas IV & Kelas V & Kelas VI \\
\hline Guru mengatur tempat duduk siswa sebelum materi dimulai & 2 & 3 & 3 \\
\hline $\begin{array}{l}\text { Guru menegur secara halus siswa yang tidak memperhatikan } \\
\text { penjelasan guru }\end{array}$ & 3 & 3 & 3 \\
\hline $\begin{array}{l}\text { Guru memberikan pertanyaan terbuka untuk mengecek } \\
\text { pemahaman siswa tentang materi yang diberikan }\end{array}$ & 2 & 3 & 4 \\
\hline $\begin{array}{l}\text { Sebagian besar siswa melaksanakan tugas yang diberikan dengan } \\
\text { serius }\end{array}$ & 3 & 2 & 3 \\
\hline $\begin{array}{l}\text { Guru berjalan berkeliling kelas sambil membimbing siswa } \\
\text { mengerjakan lembar kerja }\end{array}$ & 3 & 4 & 4 \\
\hline $\begin{array}{l}\text { Guru meminta salah satu siswa untuk pindah tempat duduk ke } \\
\text { barisan depan }\end{array}$ & 3 & 2 & 2 \\
\hline Skor & 16 & 17 & 19 \\
\hline
\end{tabular}

Sumber : Olahan Data Primer

Kompetensi Pedagogik Guru dalam Meningkatkan Mutu Pembelajaran Siswa di SD Negeri 19 Mandau

Kompetensi merupakan hal yang harus dimiliki oleh guru, sebagai salah satunya yaitu kompetensi pedagogik.

Kompetensi pedagogik merupakan kemampuan guru dalam mengelola pembelajaran peserta didik.

Kompetensi ini meliputi kemampuan guru dalam mempersiapkan perencanaan pembelajaran guru menyiapkan perangkat pembelajaran berupa prota, promes, silabus, RPP, metode dan media. Temuan tersebut menguatkan Peraturan Pemerintah Nomor 19 Tahun 2005 Bab IV pasal 20 yang menyatakan bahwa perencanaan proses pembelajaran meliputi silabus dan Rencana Pelaksanaan Pembelajaran yang memuat sekurang-kurangnya tujuan pembelajaran, materi ajar, metode pembelajaran, sumber belajar, dan penilaian hasil belajar.

Kompetensi Pedagogik guru di SD Negeri 19 Mandau bisa ditinjau melalui perancangan perangkat pembelajarannya. Seorang guru dalam penerapan pembelajaran harus menggunakan perangkat pembelajaran. Suatu perangkat pembelajaran digunakan untuk sebagai titik acuan guru dalam pembelajaran di kelas. Tanpa adanya suatu perangkat pembelajaran seorang guru tidak bisa melaksanakan pembelajaran di kelas dengan baik.

Dari wawancara Kepala Sekolah dengan Waka kurikulum yakni ibu Nani Wati mengatakan bahwa: Perangkat pembelajaran yang digunakan para guru untuk mempermudah proses pembelajaran atau bisa 
dikatakan panduan dalam melaksanakan pembelajaran. Dan di SD Negeri 19 Mandau disini semua guru sudah membuat perangkat pembelajaran jauh- jauh hari sebelum Kegiatan Belajar Mengajar akan di mulai mas, dalam pembuatan perangkat pembelajaranya dilakukan pada waktu awal tahun ajaran, peserta dalam penyusunannya yaitu melalui MGMP (Musyawarah Guru Mata Pelajaran) yang materinya sesuai dengan Kurikulum 2013. Seorang guru harus membuat dan mempunyai Perangkat Pembelajaran baik itu berupa silabus, prota, promes dan RPP. Perangkat pembelajaran dijadikan sebagai patokan guru untuk mengajar di dalam kelas, menentukan tujuan pembelajaran. Tanpa adanya perangkat pembelajaran maka guru tesebut tidak bisa melaksanakan pembelajaran di kelas dengan baik.

Pentingnya perangkat pembelajaran hal ini membuktikan adanya kemampuan atau kompetensi pedagogik yang dimiliki oleh guru. Dilihat dari pemaparan ibu Ermawati sebagai wali kelas 6 , bahwa: Penyusunan perangkat pembelajaran selalu dilakukan sebelum memasuki tahun ajaran baru. Semua guru menyesuaikan dengan kurikulum yang akan ditetapkan dalam instansi sekolah. Para guru membuat perangkat pembelajaran masing-masing dengan berbagai mata pelajaran yang akan diajarkan. Kalau untuk bentuk kerjasamanya itu bisa berupa seperti mencocokkan model pembelajarannya itu seperti apa. Contoh, apabila seorang guru melakukan satu model pembelajaran tetapi tidak berhasil berarti itu perlu dicari penyebab dan solusinya. Entah itu perlu diganti dengan model yang baru atau tetap menggunakan model itu. Perangkat untuk seorang guru itu dijadikan patokan dalam pembelajaran di kelas, seorang guru yang akan mengajar di kelas harus siap dengan perangkat pembelajaran-nya. Apabila guru tersebut tidak mempunyai perangkat pembelajaran, maka guru tersebut sudah melanggar tata tertib sebagai seorang guru. Jadi perangkat pembelajaran merupakan suatu landasan dasar oleh para guru.

Adanya perangkat pembelajaran dapat memberikan kemudahan pada guru untuk menyampaikan materi, karena di awal pembuatan perangkat pembelajaran didalamnya juga mengkaji tentang materi pembelajaran yang sesuai dengan tingkat kemampuan anak didik untuk disampaikan dengan mengkaji dari aspek bahasan, bahasa dan sebagainya. Sehingga dari sini bisa di tarik kesimpulan, kompetensi pedagogik pada guru dalam meningkatkan mutu pembelajaran siswa bisa dilihat dari pemaparan tersebut. Perangkat pembelajaran sesuai dengan kurikulum yang dipakai dan akan di implementasikan di sekolah tersebut. Hal di atas dibenarkan oleh Ibu Sayfni Yetti menyatakan bahwa:

"Di awal tahun ajaran baru sudah ada anjuran untuk membuat perangkat pembelajaran. Jadi kita semua para guru berkumpul jadi satu yang berasal dari sekolah-sekolah yang lain dan menyusun perangkat pembelajaran yang mana nanti akan di implementasikan di lembaga masing-masing namun dalam penyusunan perangkat pembelajaran tidak mengabaikan terkait tingkat perkembangan anak didik."

Untuk menunjang kompetensi pedagogik guru dalam dalam menyusun perangkat pembelajaran, dilaksanakan musyawarah atau perkumpulan untuk pembuatan perangkat pembelajaran. Dari sini guru bisa memberikan wacana yang bagus untuk memilah dan memilih materi, metode, media, dan sebagainya untuk menunjang pembelajaran siswa yang tujuannya dalam meningkatkan mutu pembelajaran. Terlaksananya pembelajaran yang baik dan efektif menjadi tujuan pembelajaran oleh guru. Selain dapat menyusun dan membuat perangkat pembelajaran, mengembangkan kurikulum juga sangat dibutuhkan. Usaha para guru dalam pengembangan perangkat pembelajaran bisa di lakukan dengan mengikuti adanya workshop dari dinas pendidikan. Hal itu sesuai dengan penjelasan dari ibuk Nani wati , yang menuturkan bahwa:

Upaya dari para guru juga harus dituntut untuk mengembangkan perangkat pembelajaran yang telah disusun dari organisasi MGMP, Di sini Bapak Ibu guru sering mengikuti workshop. Dari guru-guru sering workshop yang diselenggarakan oleh dinas pendidikan. Dengan adanya workshop ini ditujukan agar Bapak Ibu guru banyak mendapatkan wawasan yang lebih dalam pengembangan perangkat pembelajarannya. Dengan mengadakan workshop inilah diharapkan proses pembelajaran agar lebih bermutu. Selain itu, kegiatan ini juga dapat meningkatkan kreatifitas guru dalam menggunakan metode pembelajaran yang diharapkan agar proses penyampaian materi pembelajaran dapat berjalan lancar dan menjadi berkualitas.

Sesuai dengan hasil observasi peneliti pada saat wawancara, berikut paparannya:

"Dengan adanya pengembangan kurikulum, guru dituntut agar bisa mengembangkan juga. Peneliti menanyakan terkait pelatihan workshop dalam pengembangan kurikulum. Disini guru dituntut untuk mampu memeilih, menyusun dan menata materi pembelajaran yang sesuai dengan kebutuhan anak didik."

Selain membuat perangkat Pembelajaran seorang guru juga harus bisa memahami karakter peserta didik. dan untuk mengetahuinya itu, guru melakukan tes kepada siswa. Hal ini di jelaskan oleh Ibu Ermawati, bahwa:

"Melihat karakter peserta didik saya biasanya melakukannya dengan menggunakan tes. Tes disini saya lakukan melalui pembelajaran. Dengan melakukan tanya jawab dan melalui kegiatan yang ada disekolah. Dengan otomatis 
kita bisa menjadi tahu bagaimana karakter para siswa satu persatu. Pemahaman terkait dengan karakter siswa itu saya dengan cara tanya jawab dan juga mengamati terkait kegiatan yang dilakukan oleh siswa, dan saya dengan mudah dapat menyimpulkan bagaimana karakter siswa tersebut. Atau dengan memperhatikan siswa ketika di dalam kelas, adanya tanya jawab antara guru dengan siswa akan mempermudah guru untuk memahami karakter siswanya

Pemaparan diatas ditambahkan dengan hasil observasi yang dilakukan Kepala Sekolah, ketika berada diruang kelas 5, berikut hasilnya:

"Ketika peneliti masuk kedalam kelas 5, peneliti menyaksikan bahwa guru sedang melakukan tanya jawab untuk mengenal karakter siswanya. Guru memberikan pertanyaan secara langsung kepada siswa dan siswa langsung menjawab apa saja pertanyaan dari guru tersebut."

Dalam hal ini di kuatkan dengan hasil dokumentasi pada saat peneliti berada di ruang kelas untuk melakukan observasi kepada guru yang sedang melakukan tanya jawab terkait mengenali karakter siswanya. Kegiatan yang dilakukan oleh guru untuk memperdalam pengetahuan guru dalam melaksanakan KBM, maka ada hal yang perlu diketahui yaitu adalah memahami karakter siswa. Dari sini ada beberapa cara untuk memahaminya yaitu dengan penggunaan cara seperti tanya jawab, mengamati kegiatan siswa dan sebagainya. Karakter siswa sudah di ketahui oleh guru, maka tindakan selanjutnya adalah menentukan model dan metode pembelajaran yang digunakan dalam penyampaian materi. Hal itu sebagai salah satu upaya yang dilakukan oleh guru untuk memudahkan penyampaian materi. Sejalan dengan pemaparan oleh Ibu Fitri Yenti, selaku Guru kelas 4 menuturkan bahwa:

"Dalam penyampian materi di kelas, saya menggunakan metode ceramah. Tapi juga tidak terus-terusan hanya ceramah. Apabila anak mulai bosan maka metode akan saya ganti dengan menggunakan CTL, metode diskusi dan tanya jawab. Anak akan lebih aktif dan fokus dalam menerima pelajaran yang saya sampaikan".

Hal senada juga dijelaskan oleh Ibu Ermawati, bahwa:

"Saya paling sering memakai metode ceramah, diskusi, tanya jawab. Dengan adanya banyak bervariasi metode yang saya gunakan harapannya adalah jangan sampai anak hanya paham dengan materinya saja, tapi siswa juga harus tahu di lapangan. Tidak hanya terfokus dalam kelas saja".

Hal senada juga dijelaskan oleh Ibu Nani Wati, selaku Guru kelas 5 , bahwa:

"Penggunaan metode pembelajaran sangat berpengaruh terhadap prestasi belajar peserta didik. Apabila metode yang digunakan guru sesuai dengan materi yang akan disampaikan hal ini akan kelihatan dari hasil belajar peserta didik yang baik. Oleh karena itu, dalam merencanakan suatu pelaksanaan pembelajaran harus di pertimbangkan karakteristik peserta didik. Sebab berhasil tidaknya materi yang di berikan guru sangat bergantung dari kesiapan peserta didik untuk menerimanya.

Data didukung dengan observasi metode pembelajaran yang digunakan guru kelas $\mathrm{V}$ yang disesuaikan dengan materi pelajaran, kompetensi yang dicapai dan karakteristik peserta didik hal itu dapat dibuktikan peneliti ketika proses pembelajaran berlangsung di kelas. Guru menggunakan metode ceramah, tanya jawab, penugasan dan diskusi kelompok. Jadi dalam proses pembelajaran guru dapat mengombinasi berbagai macam metode pembelajaran. Jadi, dapat disimpulkan bahwa terdapat banyak metode pembelajaran seperti : CTL, ceramah, diskusi, tanyajawab dsb. merupakan beberapa metode yang diterapkan oleh guru yang ada di SD Negeri 19 Mandau. Hal tersebut sebagai upaya guru dalam memudahkan peserta didik untuk memahami materi ajar. Dari sini memberikan gambaran bahwa kemampuan guru memiliki penguasaan metode pembelajaran. Selain metode yang harus dikuasai oleh guru, seorang guru juga dituntut untuk mampu menggunakan media belajar sebagai alat pendukung untuk mencapai tujuan pembelajaran yang telah ditetapkan. Seiring dengan perkembangan ilmu pengetahuan dan teknologi,seorang guru harus terus-menerus untuk mengembangkan potensi dirinya agar wawasan menjadi luas sehingga dapat mengikuti perubahaan. Kemampuan ini pada dasarnya merupakan kemampuan guru dalam mencipatakan kondisi belajar yang merangsang anak didik agar proses belajar mengajar dapat berlangsung secara efektif dan efisien. Guru menggunakan media gambar ini, yang nantinya juga akan digunakan untuk evaluasi pada akhir pembelajaran . Hal senada juga disampaikan oleh Ibu Ermawati bahwa:

"Dalam menyapaikan materi saya juga sering menggunakan media pembelajaran, seperti ketika meteri yang diajarkan yang berhubungan dengan komputer, siswa saya ajak pratek langsung ke laboratorium komputer yang telah disediakan oleh sekolah masing-masing, agar siswa tersebut mengetahui secara langsung tidak hanya mengetahui gambarnya saja."

Dari penjelasan di atas tentunya dalam suatu pembelajaran harus ada evaluasi, terkait hal-hal yang telah dilakukan oleh seorang guru. Evaluasi sebagai cara guru untuk mengetahui keberhasilan proses pembelajaran yang telah dilkakukan, maka diperlukan adanya evaluasi dalam pembelajaran, baik evaluasi terkait bahan 
ajar, rencana pembelajaran, pemilihan model dan metode pembelajaran ataupun masalah-masalah yang dihadapi oleh guru didalam kelas. Evaluasi ini bisa di lakukan dengan berbagai cara. Hal ini di utarakan oleh Ibu Nani Wati, bahwa :

"Evaluasi secara umum terkait proses pembelajaran harus dilakukan oleh semua guru, dilembaga sini evaluasi bersama-sama oleh guru terkait masalah-masalah yang dihadapi didalam kelas dilakukan setiap satu bulan sekali. Namun sebelum itu guru-guru disini selalu malakukan shearing dengan guru yang sama dengan kelas yang sama, contoh guru kelas 5 tukar pikiran dengan guru kelas 5 dan seterusnya. Pada evaluasi pembelajaran juga terdapat penilaian proses dan penilaian hasil. Penilaian proses biasanya dilakukan pada saat pembelajaran berlangsung, misalnya keaktifan di dalam kelas sedangkan penilaian hasil dilaksanakan setelah pembelajaran, misalnya evaluasi pembelajaran dalam bentuk tertulis, lisan, maupun praktik. Ini berlaku untuk semua proses pembelajaran.

Evaluasi dilakukan akhir pembelajaran yaitu guru memberi pertanyaan secara lisan kepada peserta didik tentang materi yang telah disampaikan. Guru melakukan evaluasi berupa tes tulis berupa kuis yang solanya dibacakan oleh guru sedangkan peserta didik tinggal menulis jawabannya saja. Ketika proses pembelajaran guru juga memberikan penilain sikap terhadap peserta didik. Dari pemaparan yang ada, dapat ditarik kesimpulan bahwa tehnik evaluasi yang dilakukan oleh guru bisa berupa tes langsung dan tidak langsung. Secra langsung yakni guru melakukan tanyajawab. Yang tidak langsung yakni guru memberikan tugas-tugas, ulangan harian dsb. Supaya guru bisa melihat keberhasilan proses KBM yang sudah berlangsung, sehingga guru memiliki gambaran atau rencana baru dalam meningkatkan proses pembelajaran. Selain itu, guru juga bisa memperbaiki kegiatan belajar mengajar yang sudah dijalankan. Hal ini bertujuan untuk mengetahui cara meningkatkan potensi anak dari aspek psikomotorik, afektif dan kognitif yang berkaitan dengan pelajaran.

Temuan tersebut sesuai dengan Peraturan Menteri Pendidikan dan Kebudayaan Nomor 65 Tahun 2013 tentang Standar Proses disebutkan bahwa setiap pendidik pada satuan pendidikan berkewajiban menyusun perangkat pembelajaran secara lengkap dan sistematis agar pembelajaran berlangsung secara interaktif, inspiratif, menyenangkan, menantang, memotivasi peserta didik untuk berpartisipasi aktif, serta memberikan ruang yang cukup bagi prakarsa, kreativitas, dan kemandirian sesuai dengan bakat, minat, dan perkembengan fisik serta psikologis peserta didik. Untuk itu setiap satuan pendidikan perlu melakukan perencanaan pembelajaran, pelaksanaan proses pembelajaran serta penilaian proses pembelajaran dengan strategi yang benar untuk meningkatkan efesiensi dan efektivitas ketercapaian kompetensi kelulusan (Kemdikbud, 2013).

Selain itu juga pengembangan kurikulum, memahami karakter peserta didik, menyiapkan strategi dalam pembelajaran, dan mengadakan evaluasi pembelajaran. Guru di SD Negeri 19 Mandau dalam menyusun perencanaan pembelajaran, memilih materi ajar peserta didik yang disesuaikan dengan kebutuhan. Selain itu, penyesuaian juga diterapkan pada strategi, model, metode, teknik pembelajaran.

Untuk itu, kompetensi pedagogik guru inilah yang akan mengantarkannya dalam meningkatkan mutu pembelajaran di SD Negeri 19 Mandau Berawal dari pembuatan perangkat pembelajaran, untuk mempermudah rencana pembelajaran guru terlebih dahulu mengenali karakter peserta didik. Hal ini bertujuan agar memudahkan guru memilih materi yang disesuaikan dengan kebutuhan peserta didik. Setelah perangkat pembelajaran terbentuk maka hal yang dilakukan guru adalah melaksanakan pembelajaran sesuai dengan perangkat pembelajaran yang telah dibuat. Pelaksanaan proses belajar mengajar di kelas, guru menggunakan beberapa model, strategi dan metode mengajar agar semua peserta didik dapat memahami materi yang disampaikan dengan susana yang kondusif dan menyenangkan. Metode yang digunakan guru di kedua lembaga tersebut bervariasi meliputi metode ceramah, tanya jawab, role playing, inkuiri, penugasan dan diskusi kelompok. Dan juga penggunaan media pembelajaran sebagai pendukung untuk menpai tujuan dan memudahkan guru dalam menyampaikan meteri ajar, diantaranya menggunakan media audio visual dan media visual, hal ini tidak terlepas dari kreatifitas guru di kedua lembaga tersebut. Dalam proses pembelajaran guru tidak selalu menggunakan media pembelajaran.

\section{Kompetensi Profesional Guru dalam Meningkatkan Mutu Pembelajaran Siswa di SD Negeri 19 Mandau}

Kompetensi profesional bagi seorang guru adalah kemampuan penguasaan materi pembelajaran secara luas dan mendalam yang memungkinkan membimbing peserta didik memenuhi standar (Dudung, 2018; Hasan, 2019; Nurtanto, 2016). Tugas guru sebagai pendidik haruslah melakukan tugas dan fungsinya sebagai guru dengan kemampuan yang maksimal atau profesional. Kompetensi profesional adalah kemampuan penguasaan materi pembelajaran secara luas dan mendalam yang memungkinkan membimbing peserta didik memenuhi standart kompetensi yang ditetapkan dalam standar nasional pedidikan. Untuk itu, kompetensi profesional memang harus dimiliki oleh seorang pendidik agar tugas dan tanggung jawabnya bisa berjalan dengan sempurna. Sehubungan dengan kompetensi profesional. Di SD Negeri 19 Mandau, para guru berkompeten dalam bidangnya dalam artian kemampuan guru dalam penguasaan materi pembelajaran secara 
luas dan mendalam yang memungkinkannya membimbing siswa dalam memenuhi standar kompetensi. Dimulai dari menggunakan model pembelajaran serta berbagai metode dalam penyampaian materi pelajaran. Seorang guru menyampaikan konsep pelajaran kepada siswa secara profesional agar peserta didiknya lebih memahami terkait pelajaran yang akan diajarkan oleh guru tersebut.

Seorang guru bisa dikatakan berbakat dalam profesinya manakala guru itu memiliki cara dalam mengatasi hambatan-hambatan yang ada ketika KBM berlangsung. Selain itu guru mampu memberikan kemudahan kepada siswa untuk memahami materi yang diajarkan. Sejalan dengan hal tersebut sesuai dengan pemaparan Zulfikar, bahwa:

"Proses pembelajaran yang dilakukan seorang guru dapat dikatakan berkualitas apabila dia bisa menyampaikan pembelajaran di kelas dan para siswanya bisa menangkap apa yang telah disampaikan oleh guru tersebut dengan maksimal. Penyampaian materi pembelajaran yang dilakukan oleh guru sesuai rancangan yang telah di buat oleh guru tersebut. Bagaimana guru tersebut menyampaikan materi di kelasnya itu bisa dengan mudah dilakukan oleh gurunya, karena dia sudah mengerti betul bagaimana keadaan para siswanya. Jadi guru tinggal mudah untuk memahami berbagai karakter siswanya sehingga itu semua mempermudah guru untuk menyampaikan materinya kepada siswanya di kelas."

Ketika Peneliti memasuki ruangan untuk melihat kegiatan belajar mengajar di kelas, berikut adalah hasil observasinya: "Ketika peneliti di dalam kelas, sebelum penyampaian materi di awali dengan pembiasaan yang dilakukan oleh semua siswa yaitu menghafal surat-surat pendek dan memberikan semangat kepada siswa. Setelah itu baru guru baru menjelaskan materi pelajaran. Pada saat guru sedang menerangkan materi pelajaran, anak-anak memperhatikan dengan sungguh-sungguh apa yang telah diterangkan guru di depan kelas. Dari stimulus yang diberikan oleh guru sehingga banyak siswa yang merespon materi yang disampaikan, bahkan guru tidak melarang semua siswa untuk bertanya sebanyak-banyaknya agar mereka semua paham dengan materi yang telah disampaikan. Dari observasi inilah terlihat proses pembelajaran yang dilakukan guru bagus. Di samping itu, agar proses pembelajaran lebih baik, guru selalu berusaha dalam mengoptimalkan proses penyampaian materi pembelajaran kepada siswa." Untuk memahamkan siswa terkait materi yang diajarkan terdapat berbagai variasi metode pembelajaran yang diterapkan oleh guru yaitu sesuai dengan pemaparan Ibu Nani Wati Beliau menuturkan:

"Peran guru dalam menyampaikan materi pelajaran harus menguasai berbagai macam metode, maka dari itu para guru di sini harus menggunakan lebih dari 3 metode pembelajaran. Apabila guru menggunakan 2-3 metode pembelajaran dalam seminggunya maka harus berbeda dengan yang sudah digunakan. Bisa dilihat Mas, karena banyaknya metode dalam pembelajaran, jadi setiap guru harus bisa menggunakan berbagai metode yang ada dalam pembelajaran namun harus sesuai materi yang akan disampaikan, supaya lebih bervariasi dalam mengajar di kelas agar pembelajaran didalam kelas tidak terkesan monoton."

Sedangkan Ibu Nani Wati menyatakan bahwa:

"Pada saat guru mengajar di kelas tidak hanya menggunakan ceramah saja, tetapi ketika para siswa yang lain sudah merasa jenuh dengan cepat guru mengganti sistem pembelajaran di kelas dengan mengadakan diskusi bersama. Nanti diadakan presentasi dan dilanjutkan dengan tanyajawab. Jadi guru lebih aktif dalam pembelajaran di kelas. Dan nanti guru akan memberikan nilai kepada murid yang aktif di kelas."

Dalam bidang kompetensi professional, guru di SD Negeri 19 Mandau, selalu berusaha untuk meningkatkan mutu dalam proses pembelajaran. Di sini tidak hanya menggunakan berbagai metode dalam pembelajaran. Dalam menjalankan profesinya seorang guru haruslah dapat bersikap profesional. Dalam artian dari sisi pengetahuan, keterampilan, dan sejenisnya harus sesuai dengan pengetahuan khusus yang dimilikinya. Hal tersebut bertujuan untuk memberikan tanggung jawab kepada guru terhadap profesi yang dimilikinya dan profesionalitas guru-guru yang ada sudah terkualifikasi dengan sempurna sehingga guru bisa menjalankan tugasnya dengan baik.

Untuk memahamkan siswa terkait materi yang diajarkan oleh guru terdapat, guru tidak hanya menggunakan satu buku saja, namun juga menggunakan buku yang lain yang relevan dengan materi agar penguasaan materi yang dimiliki oleh guru lebih luas dan dalam, selain itu guru juga memanfaatkan perpustakaan yang telah disediakan oleh sekolah. Sehingga di jelaskan juga:

"dalam pembelajaran dikelas para guru disini dalam penyampaian materi pelajaran tidak hanya menggunakan satu buku pegangan guru saja, namun juga dituntut mencari meteri dari sumber lain yang sesuai dengan materi yang disampaikan kepada siswa, agar guru tersebut dapat menguasai meteri yang lebih luas tidak hanya mengacu pada satu buku saja mas, selain itu disini juga menyediakan perpustakaan guna untuk menunjang proses pembelajaran." 
Sedangkan Ibu Ermawati menjelaskan

"pada saat penyampaian meteri saya tidak hanya menggunakan satu buku saja, saya juga menggunakan buku yang lain namun masih berkaitan dengan materi yang saya sampaikan kepada siswa. Karena buku yang jadi pegangan guru saat ini materinya sedikit sehingga saya harus mencari materi dari sumber lain agar materi yang saya kuasai lebih luas. Jadi seorang guru dituntut untuk bisa mengembangkan materi pelajaran.

Dari pemaparan tersebut juga didukung dengan hasil observasi pada saat peniliti memasuki kelas, pada saat KBM berlangsung. "peneliti mengamati guru dalam menyampaikan materi, pada saat penyampaian materi guru tidak mengacu pada satu buku, namun guru juga mengambil dari materi dari sumber lain dengan menggunakan buku-buku yang disediakan oleh sekolah. Dalam penyampaian materi siswa dapat memahami materi yang disampaikan oleh guru.

Hal senada juga disampaikan oleh bapak Zulfikar bahwa:

"selain guru dituntut untuk menguasai berbagai macam model dan metode pembelajaran, guru disini juga harus dituntut untuk mampu mengembangkan materi ajar, karena buku pegangan guru saat ini yang diberikan oleh dinas, materinya hanya sedikit sehingga hal tersebut menuntut guru harus mengembangakan materi sendiri, hal tersebut terlihat bahwa saat ini kita meggunakan kurikulum 2013 yang mana materi didalamnya menggunakan tema-tema dan dan kurang luas. Untuk mengatasi hal tersebut saya pribadi menggunakan sumber dari buku lain, seperti menggunakan buku- buku dari perpustakaan dsb sehingga materinya yang dipelajari lebih dalam dan luas. Di samping guru dituntut untuk mengembangkan materi pelajaran, guru juga dituntut untuk mampu mengorganisasikan berbagai materi, karena dalam kurikulum 2013 materinya bertema-tema dan dalam setiap tema berisi beberapa meteri seperti: matematika, Bahasa indonesia, IPA, dan IPS. Dari keempat materi tersebut tercantum pada satu tema, jadi guru harus bisa menghubungkan materi satu dengan materi selanjutnya"

Dari pemaparan diatas membuktikan bahwa kompetensi professional yang dimiliki oleh guru di SD Negeri 19 Mandau bagus,selain penguasaan materi secara mendalam guru juga dituntut untuk bisa menguasai kelas, dalam artian guru tersebut mampu untuk mengelola kelas pada saat KBM.

Kompetensi profesional guru di SD Negeri 19 Mandau diwujudkan melalui pengelolaan kelas dan penguasaan materi ajar, langkah yang diambil untuk memahami materi yang akan diajarkan kepada peserta didik maka guru disana senantiasa mengupdate informasi terkait materi ajar melalui jalan mencari informasi di berbagai sumber seperti membaca buku- buku terbaru, mengakses dari internet. Selain itu dari pihak sekolah juga menyediakan beberapa sumber bahan ajar yang sudah tersedia di perpustakaan sekolah sehingga dari kegiatan tersebut guru mampu menjalankan tugasnya dengan lancar dan terencana. Dari penguasaan materi yang didapat kemudian dipilah-pilah sesuai dengan apa yang dibutuhkan oleh peserta didik. Penyampaian materi ini dikelola oleh guru melalui keterampilan yang dimiliki dari penggunaan media, metode dan alat yang tersedia di sekolah.

Kompetensi Kepribadian Guru dalam Meningkatkan Mutu Pembelajaran Siswa di SD Negeri 19 Mandau Kompetensi kepribadian adalah kompetensi yang berkaitan dengan perilaku pribadi guru itu sendiri yang harus memiliki nilai-nilai luhur sehingga terpancar dalam perilaku sehari-hari (Napitupulu, 2016). Sehingga kompetensi kepribadian ini dijadikan wadah oleh guru dalam berkomunikasi dan berinteraksi pada lingkungan sekitar. Khususnya untuk tugasnya sebagai guru, maka kompetensi kepribadian ini memberikan ruang gerak terhadapnya dalam membimbing, mengarahkan dan membantu peserta didik untuk memegang nilai-nilai akhlakul karimah.

Seorang guru yang menjadi center piece terletak pada kepribadiannya. Bagaimana guru tersebut menjadi suri tauladan bagi siswanya. Guru mempunyai tanggung jawab yang besar terhadap pekerjaannya. Hal ini sesuai dengan yang dituturkan oleh Ibu Nani Wati:

"Seorang guru harus dengan sepenuh hati dalam melakukan pekerjaannya. Selalu datang ke kelas tepat waktu juga merupakan kewajiban guru. Guru diharuskan untuk disiplin waktu, disiplin disini mengandung arti bahwa seorang guru harus bertanggung jawab terhadap kehadirannya mengajar siswa di kelas. Tidak boleh sering terlambat datang ke kelas atau bahkan tidak mengajar di kelas. Keterlambatan itupun sudah ada tolerir dari pihak sekolah. Guru maksimal telat datang pukul 07.00, itupun minimal sudah ada di ruang piket. Tapi anjuran utamanya 07.15 sudah harus mendampingi siswa di kelas. Toleransi pergantian jam pelajaran pun dikasih waktu maksimal 5 menit untuk menuju ke ruang kelas. Profesional guru harus ditingkatkan, jadi semaksimal mungkin guru harus bertanggung jawab dengan pekerjaannya.

Paparan di atas diperjelas oleh Ibu Ermawati selaku bahwa:

"Disiplin waktu sangat penting untuk seorang guru, sisi kepribadian guru dapat dilihat melalui kebiasaannya yang nampak. Seperti telat datang ke kelas atau sering terlambat datang ke sekolahan. Guru harus memberikan 
contoh yang baik kepada para siswanya, tidak hanya memberikan hukuman kepada para siswa karena siswa tersebut sering melakukan keterlambatan. Kebiasaan guru yang baik akan selalu di contoh oleh murid-muridnya, dan begitupun sebaliknya. Kebiasaan yang agak buruk akan digunakan siswa untuk kelemahan gurunya".

Hal tersebut menunjukan bahwa kepribadian guru ada, yakni disiplin waktu, tanggung jawab, kesadaran akan kewajibannya sebagai guru sangat berpengaruh pada peningkatan mutu pembelajaran siswa. Guru memberikan contoh yang baik kepada siswa melalui tindakan. Apabila guru tidak memberikan contoh yang baik maka guru tersebut akan mendapatkan punishmen dari aturan yang berlaku di sekolah. Jadi tidak hanya siswa yang mendapatkan hukuman, gurupun juga akan mendapatkan hal yang sama apabila dia melakukan pelanggaran. Hal itu sesuai dengan yang dituturkan oleh Bapak Zulfikar bahwa:

"Guru harus tertib, guru kita dituntut agar profesional menjalankan pekerjaaanya. Kita sangat tertib dengan aturan yang sudah di buat dari sekolah. Murid yang terlambat akan dihukum begitupun dengan guru yang terlambat, mereka akan juga mendapatkan hal yang sama"

Hal senada juga dituturkan oleh Ibu syafni yetti:

"Apabila guru datang terlambat maka juga harus mendapatkan sanksi yang telah disepakati oleh semua guru SD

Negeri 19 Mandau. Saya mau memberikan penjelasan sedikit. Di sini guru datang telat juga ada potong gaji, dan guru yang tidak masuk juga potong gaji. Potong gaji ini tidak diberlakukan setiap melakukan kesalahan, namun kalau si guru tersebut telah mencapai puncak toleransinya maka akan diberlakukan potong gaji tersebut.

Dengan tertibnya kepala sekolah akan menciptakan guru-guru menjadi tertib pula. Dan begitupun seterusnya, apabila guru sudah tertib maka para siswa itupun akan tertib dengan sendirinya. Karena mereka sudah mempunyai panutan yang benar untuk di contoh. Dari sinilah terlihat usaha meningkatkan mutu pembelajaran. Pembelajaran dapat dikatakan bermutu salah satu aspek yang harus dipenuhi adalah siswa harus berperilaku disiplin. Ketika siswa disiplin dalam kesehariaanya, maka secara tidak langsung siswa akan disiplin dalam proses belajarnya. Setiap subjek mempunyai pribadi yang unik, masing-masing mempunyai ciri dan sifat bawaan serta latar belakang kehidupan. Banyak masalah psikologis yang dihadapi peserta didik, banyak pula minat, kemampuan, motivasi dan kebutuhannya. Hal tersebut sesuai Keteladanan guru yang dipaparkan dalam buku Mejadi Guru Profesional, E Mulyasa menyatakan bahwa guru merupakan model atau teladan bagi para peserta didik dan semua orang yang menganggap dia sebagai guru. Terdapat kecenderungan yang besar untuk menganggap bahwa peran ini tidak mudah untuk ditentang, apalagi ditolak. Menjadi teladan merupakan sifat dasar kegiatan pembelajaran, dan ketika seorang guru tidak mau menerima ataupun menggunakannya secara konstruktif maka telah mengurangi keefektifan pembelajaran. Peran dan fungsi ini patut dipahami, dan tak perlu menjadi beban yang memberatkan sehingga dengan keterampilan dan kerendahan hati akan memperkaya arti pembelajaran.

\section{Kompetensi Sosial Guru dalam Meningkatkan Mutu Pembelajaran SD Negeri 19 Mandau}

Kompetensi sosial guru merupakan kemampuan guru untuk memahami dirinya sebagai sebagai bagian yang tidak terpisahkan dari masyarakat dan mampu mengembangkan tugas sebagai anggota masyarakat dan warga negara (Febriana, 2021; Harahap, 2017). Lebih dalam lagi kemampuan sosial ini mencakup kemampuan untuk menyesuaikan diri kepada tuntutan kerja dan lingkungan sekitar pada waktu membawakan tugasnya sebagai guru. Guru sebagai bagian dari masyarakat merupakan salah satu pribadi yang mendapatkan perhatian khusus di masyarakat. Peranan dan segala tingkah laku yang dilakukan guru senantiasa dipantau oleh masyarakat. Guru memiliki kedudukan khusus di mata masyarakat. Oleh karena itu, diperlukan sejumlah kompetensi sosial yang perlu dimiliki guru dalam berinteraksi dalam lingkungan masyarakat di tempat dia tinggal.

Kompetensi sosial dalam kegiatan belajar ini berkaitan erat dengan kemampuan guru dalam berkomunikasi dengan masyarakat di sekitar sekolah dan masyarakat tempat guru tinggal sehingga peranan dan cara guru berkomunikasi di masyarakat diharapkan memiliki karakteristik tersendiri yang sedikit banyak berbeda dengan orang lain yang bukan guru. Misi yang diemban guru adalah misi kemanusiaan. Mengajar dan mendidik adalah tugas memanusiakan manusia. Dengan terjaganya tali silahturahmi maka akan mengeratkan hubungan yang harmonis guru yang satu dengan guru yang lain bahkan terhadap orang lain. Guru merupakan tokoh dan tipe mahluk yang diberi tugas dan beban membina dan membimbing masyarakat ke arah norma yang berlaku. Guru perlu memiliki kompetensi sosial untuk berhubungan dengan masyarakat dalam rangka menyelenggaraka proses belajar mengajar yang efektif karena dengan dimilikinya kompetensi sosial tersebut, otomatis hubungan sekolah dengan masyarakat akan berjalan dengan lancar sehingga jika ada keperluan dengan orang tua peserta didik atau masyarakat tentang masalah peserta didik yang perlu diselesaikan tidak akan sulit menghubunginya.

Dalam hal ini Bapak Zulfikar mengatakan bahwa :

"Dalam menjalin silahturahmi guru dengan guru, guru dengan wali murid itu harus selalu berkomunikasi. Bisa dilihat dalam komunikasi yang jelas antara guru dengan wali melalui sosialisasi kegiatan, dan dengan adanya 
panggilan wali. Itu bisa meningkatkan membantu keduanya dalam meningkatkan komunikasi, pada saat ini kita diuntungkan dengan media komunikasi yang maju, guru disini dimudahkan dengan adanya aplikasi Wathsapp, guru bisa membentuk sebuah grup dengan wali murid setiap kelasnya, dan juga grup guru yang mudah untuk menginformasikan hal yang baru.

Untuk mengecek keabsahan data peneliti melakukan pengecekan keabsahan data berupa trianguasi sumber yang dituturkan oleh Ibu Ermawati bahwa :

"dalam memegang tanggungjwab yang besar seorang guru harus dituntut untuk mampu dalam interaksi dengan yang lainya, hal ini mewujudkan tali silaturrohim semakin erat. Saya pribadi untuk mengkomunikasikan terkait perkembangan anak didik saya, menggunakan grup Wathsapp, selain itu menginformasikan terkait tugas-tugas yang saya berikan kepada anak didik".

Berhubungan dengan hal tersebut Ibu Nani Wati juga menuturkan bahwa:

"Peran guru sebagai orang tua sangatlah tidak mudah. Apalagi dalam menghadapi para anak yang mengalami broken home atau mengalami kekurangan dalam menerima proses pembelajaran. Guru terus berkomunikasi dengan orang tua agar selalu memperhatikan anak-anaknya sejak usia dini. Komunikasi ini bertujuan untuk mempermudah guru dalam mengontrol keseharian anak selama di rumah, agar guru lebih mudah lagi dalam mengetahui kepribadian anak. Selain guru menjalin silahturahmi yang baik terhadap orang tua, menjalin silahturahmi dengan para siswa juga merupakan hal yang harus dilakukan oleh guru. Setelah melakukan wawancara dengan guru, berikut hasil observasinya: "Berkomunikasi dengan peserta didik pada saat jam pelajaran dengan melalui materi yang di sampaikan, sedangkan bentuk dari kegiatan luar jam pelajaran dilakukan pada saat istirahat bersama atau pada saat kegiatan ekstrakulikuler. Guru lebih bisa menjalin banyak komunikasi pada saat di luar jam pelajaran.

Sedangkan untuk memperat tali silahturahmi dengan para guru yang lain bisa dilakukan anjangsana antara guru-guru digunakan untuk sharing bersama dengan tujuan agar kerjasama antara guru semakin erat dalam ikut berjuang untuk meningkatkan pembelajaran di sekolah. Selain itu satu minggu sekali setiap malam sabtu diadakan istighosah bersama wali peserta didik dan peserta didik dengan tujuan agar pembelajaran di sekolah berjalan dengan lancar tanpa ada halangan suatu apapun serta berharap peserta didik lebih mudah menerima pembelajaran." Dari paparan di atas di simpulkan bahwa setelah melakukan wawancara kepala Sekolah dengan guru-guru maka observasinya: "Pada saat peneliti berada di SD Negeri 19 Mandau, peneliti melihat adanya perkumpulan para guru di ruang guru. Perkumpulan ini dilakukan untuk sekedar sharing antar sesama pendidik dalam menindaklanjuti evaluasi kegiatan belajar mengajar. dibina dengan sebaik mungkin agar komunikasi antar tenaga pendidik tetap terjaga. Tergambarkan jelas ketika komunikasi terjalin maka akan tercipta suasana yang harmonis. Dengan adanya pemaparan diatas dikuatkan dengan hasil dokumentasi yang diambil oleh peneliti.

Dapat diketahui bahwa kompetensi sosial yang dimiliki guru di SD Negeri 19 Mandau ditunjukkan adanya jalinan komunikasi guru dengan murid melalui kegiatan belajar mengajar. komunikasi guru di luar kelas melalui kegiatan ekstrakulikuler. Jalinan komunikasi guru dengan wali murid juga di lakukan melalui pertemuan rutin tiap minggu dan tiap semester, hal ini bertujuan mempererat jalinan komunikasi antar guru dengan wali peserta didik dan sebagai sarana untuk mengetahui perkembangan peserta didik tersebut. Dan juga pendidik dengan pendidik baik dalam satu lembaga maupun dengan lembaga yang lain hal itu diwujudkan melalui kegiatan perlombaan antar sekolah pada waktu tertentu.

\section{Simpulan}

Simpulan dari penelitian ini adalah 1) kompetensi pedagogik guru dalam meningkatkan mutu pembelajaran di SD Negeri 19 Mandau telah diterapkan oleh guru dalam proses pembelajaran dan evaluasi pembelajaran yang meliputi tiga ranah yaitu kognitif, afektif dan psikomotorik. 2) Kompetensi profesional guru dalam meningkatkan mutu pembelajaran di SD Negeri 19 Mandau telah diterapkan melalui kemampuan guru menyiapkan kelas dengan suasana yang nyaman serta proses pembelajaran yang dikemas dalam bentuk permainan, penerapan outdoor clasroom sesuai dengan kualifikasi dan kemampuan dalam bidangnya. 3) Kompetensi kepribadian guru dalam meningkatkan mutu pembelajaran di SD Negeri 19 Mandau telah diterapkan melalui disiplin waktu, selalu mentaati aturan atau kode etik guru dan bertanggung jawab atas segala tugas yang mereka ampu selama menjadi guru. 4) Kompetensi sosial guru dalam meningkatkan mutu pembelajaran di SD Negeri 19 Mandau, ditunjukan dengan jalinan komunikasi guru dengan peserta didik melalui kegiatan belajar mengajar, serta kegiatan diluar kelas melalui kegiatan ekstrakurikuler dan kegiatan lainnya. Jalinan komunikasi guru dengan orang tua melalui pertemuan setiap minggunya dan tiap semester. 5) Kemampuan guru dalam menerapkan kompetensi tersebut didukung dari kemampuan penyiapan silabus dan RPS yang menjadi acuan penerapannya dalam proses pembelajaran. 


\section{Referensi}

Aminah, S. (2018). Pentingnya Mengembangkan Ketrampilan Mendengarkan Efektif dalam Konseling. Jurnal EDUCATIO : Jurnal Pendidikan Indonesia, 4(2), 108-114.

Dudung, A. (2018). Kompetensi profesional guru. JKKP (Jurnal Kesejahteraan Keluarga Dan Pendidikan), 5(1), 919.

Febriana, R. (2021). Kompetensi guru: Bumi Aksara.

Ferdiaz Saudagar. (2014). The role of teachers social competence in ELT. Indonesian Educational Administration and Leadership Journal (IDEAL), 1(1), 61-70. journal.unja.ac.id/IDEAL/article/view/8062/9818

Gunansyah, G., Zuhdi, U., Suprayitno, S., \& Aisy, M. R. (2021). Sustainable development education practices in elementary schools. Journal of Education and Learning (EduLearn), 15(2), 178-187. https://doi.org/10.11591/edulearn.v15i2.17091

Harahap, S. S. (2017). Kompetensi Sosial Guru.

Hasan, M. (2019). Pengaruh kompetensi profesional guru terhadap kinerja guru ekonomi sekolah menengah atas Negeri di Kabupaten Gowa. Economix, 5(2).Kemdikbud. (2013). Peraturan Menteri Pendidikan dan Kebudayaan Nomor 65 Tahun 2013.

Khofifah, A., Sano, A., \& Syukur, Y. (2017). Permasalahan Yang Disampaikan Siswa Kepada Guru Bk/Konselor. Jurnal EDUCATIO: Jurnal Pendidikan Indonesia, 3(1), 45. https://doi.org/10.29210/12017271

Mâţă, L., Cmeciu, D., \& Ghiaţău, R. M. (2013). A Reference framework of pedagogical competences of language teachers in the initial training programmes. Procedia - Social and Behavioral Sciences, 93, 648-653. https://doi.org/10.1016/j.sbspro.2013.09.255

Muchlis, A. N. (2020). Pengaruh Kemampuan Manajerial Kepala Madrasah dan Iklim Madrasah Terhadap Kompetensi Kepribadian Guru MAN Se-Kabupaten Tulungagung. IAIN Tulungagung. Muslim, H. A., Japar, M., \& Yatimah, D. (2021). Social Skills : learning cycle model and student team achievement divisions ( STAD ). Jurnal EDUCATIO (Jurnal Pendidikan Indonesia, 7(1), 29-37.

Napitupulu, D. S. (2016). Kompetensi Kepribadian Guru PAI dalam Mengembangkan Ranah Afektif Siswa di MAN 2 Model Medan. TAZKIYA, 5(2).

Nurtanto, M. (2016). Mengembangkan kompetensi profesionalisme guru dalam menyiapkan pembelajaran yang bermutu. Paper presented at the Prosiding Seminar Nasional Inovasi Pendidikan.Olsson, T., \& Apelgren, K. (2010). A Swedish Persepctive on Pedagogical Competences. UPPSALA Univerity. https://mp.uu.se/documents/432512/1163536/NSHU+Eng_inlaga\%5B1\%5D.pdf/353a7746-fd1a678a-f0f9-8cffe89036ad

Syamsinar, S., \& Jabu, B. (2016). The Problems in Professional Competence of Teachers in Teaching English Subject at Vocational High Schools. ELT Worldwide: Journal of English Language Teaching, $2(2), 95$. https://doi.org/10.26858/eltww.v2i2.1690

Taniredja, T., \& Abduh, M. (2016). Pedagogical, personality, social and professional competence in correlation with teachers' performance (Correlational study of junior high school teacher at SMPN 3 Purwokerto). The 2nd International Conference on Science, Technology, and Humanity, $264-272$. https://publikasiilmiah.ums.ac.id/xmlui/bitstream/handle/11617/7485/25 TT.pdf?sequence $=1 \&$ isAllowed $=\mathrm{y}$

$\begin{array}{lllllll}\text { Unesco. (2011). Unesco ICT Competency Framework } & \text { For }\end{array}$ https://iite.unesco.org/pics/publications/en/files/3214694.pdf

Wardoyo, C. (2015). The Measurement of Teacher's Personality Competence and Performance Using Embedded Model. Journal of Education and Practice, 6(26), 18-24. https://files.eric.ed.gov/fulltext/EJ1077384.pdf 